\title{
APPROACH TO URBAN METABOLISM OF ALMASSORA MUNICIPALITY, SPAIN, AS A TOOL FOR CREATING A SUSTAINABLE CITY
}

\author{
IRENE LÓPEZ CHOFRE, ERIC GIELEN \& JOSÉ S. PALENCIA JIMÉNEZ \\ Universitat Politècnica de València [Polytechnical University of Valencia], Spain
}

\begin{abstract}
Achieving sustainable growth is a priority in the Europe 2020 Strategy. For this purpose, the 20-20-20 objective was adopted: reduce greenhouse gas emissions $20 \%$, increase the percentage of renewable energy sources by $20 \%$ and improve energy efficiency $20 \%$. In order to achieve this, the focus must be placed on cities. That is why the Community Funds Regulations establish the obligation to dedicate at least 5\% of European Regional Development Fund resources toward measures for integrated and sustainable urban development. The Operational Program of Sustainable Growth 2014-2020, intends to support cities' initiatives for changes towards an economy with low carbon emissions, to increase the use of renewable energy sources, to modernize our transport sector and to promote energy efficiency. A metabolic approach to the urban phenomenon tries to understand the city as a complex system that incorporates and transforms materials, water and energy, to ensure the different functions performed by the city, whether social, environmental or economic. The knowledge of a city's urban metabolism provides a powerful tool for analysis, planning and management, moving towards the goal of sustainability. Our research aims to model the city's urban metabolism in Almassora (Valencian community, Spain) and to demonstrate its usefulness as a methodological proposal for integrating this framework into the process of developing a strategy towards a sustainable city. The current metabolic profile of the city was generated calculating $\mathrm{CO}_{2}$ emissions and energy consumption for different urban forms of the city. This model gives us a tool to better understand city functioning in terms of urban metabolism, from the transformation of resources (input) and the efficiency of the different urban functions of the city, until waste generation (output). This paper offers a first reflection about how an urban metabolism approach can be useful as a planning tool to design strategies to reach sustainability. Keywords: urban metabolism, sustainable city, planning tool, circular economy, Almassora, Spain.
\end{abstract}

\section{INTRODUCTION}

The growth of cities is a fact that seems unstoppable. About $73 \%$ of the European population lives in cities, and this figure is expected to reach $82 \%$ by 2050 [1]. According to the European Environment Agency [2], although some improvements can be seen, especially in the field of housing and emission control technologies, the trend of urban enlargement and expansion is continuing. Urban population growth across Europe continues to be a threat to resources and environmental quality.

Without sacrificing growth, the fifth report on economic, social and territorial cohesion "Investing for Europe's Future" of the European Union (EU) [3] and the Europe 2020 Strategy set its sustainability as a priority condition. To this end, 3 targets were set (known as 20-20-20 target): to reduce greenhouse gas (GHG) emissions by $20 \%$; to increase the percentage of renewable energy sources by $20 \%$; and to improve energy efficiency by $20 \%$. At this crossroads, the greatest challenge lies in cities. The sustainability of the planet will be at stake in cities, for two reasons: First, they concentrate the largest problems, as cities are responsible for $>75 \%$ of the planet's global pollution and $70 \%$ of the energy consumed [4]. Secondly, they are the space with the greatest capacity to reach a reduction of environmental impacts. This desire to have a direct impact on cities is what reflects the EU policy defined in the Community Fund Regulations, which require at least 5\% of European Regional 
Development Fund (ERDF) resources to be devoted to integrated and sustainable urban development measures in cities. Under the Sustainable Growth Operational Programme 2014-2020, the aim is to support a shift towards a low-carbon economy, increase the use of renewable energy sources, modernise the transport sector and promote energy efficiency.

In this context, the "metabolic approach" to the urban phenomenon provides a useful tool for understanding the city. This is precisely the main objective of our research: to provide data on the metabolic functions of the urban fabric that allow us to demonstrate the usefulness of urban metabolism for the knowledge and modelling of the city, thus constituting a powerful tool for analysis, planning and urban management to work towards the goal of sustainability.

Within the framework of this main objective, our research aims to analyse the city in relation to consumption and emissions, focusing on building. This study will be applied to the city of Almassora, Spain (in the province of Castellón, in the Comunitat Valenciana).

The article is structured in 6 sections. The second section will describe the current conceptual framework in relation to urban metabolism. The third section will explain the methodology followed. The fourth section will provide the results obtained in terms of consumption and $\mathrm{CO}_{2}$ emissions of building. In the fifth section, our results will be analysed in relation to the growth of the city and the different developed urban forms; and finally, some conclusions will be drawn.

\section{URBAN METABOLISM}

Cities are spaces with a population concentration where economic, social and environmental activities are developed, constituting a complex system of production, transformation and exchange of goods and services that society demands to improve its social welfare. The processes generated in the system that cities make up require raw materials that are transformed and manipulated, resulting in a partial use of the generated product and a rejection of the waste produced in that process. The purpose of urban metabolism is to analyse and diagnose this type of processes that occur in cities, in order to improve the efficiency to reduce the consumption of raw materials (or resources) and the generated waste, maximising recycling of the rejects obtained during the production of goods and services.

The concept of urban metabolism can originally be contextualized in the work of Abel Wolman [5], which focuses on the effects on water and air quality in US cities, accusing an intensification of the loss of this quality as a consequence of rapid urbanization and industrialization. Wolman defined a city's metabolic requirements as all the materials and raw materials necessary to maintain the inhabitants of a city at home, at work and in leisure. From this first approach, the concept of urban metabolism was developed from various disciplines, such as urban ecology, industrial ecology, ecological economics, political ecology and political geography, as the most noteworthy [6]. Urban ecology compares the city with a natural system, in the biological sense. The city is seen as an ecosystem integrated into a larger system, and the notion of metabolism is used to describe the interrelationships between the numerous subsystems of an urban region, in order to understand how cities process energy or matter in relation to their environment [7], [8].

On the other hand, the concept of urban metabolism derives directly from the metaphorical application of industrial ecology to urban systems. Urban systems are open systems characterized by the interconnection of various subsystems (social, economic, institutional) that interact with the environment through the consumption of materials and energy, which are used to build and produce various products, generating solid, liquid and gaseous waste that is absorbed and regenerated by the environment [9]. 
From the perspective of a green economy, the view of urban metabolism is restricted to the laws of thermodynamics from a mercantilist or economic point of view, as it is considered that the economy is integrated into an organized system that transforms raw materials and low entropy energy into high entropy and non-energy waste [10].

Urban political ecologists focus on understanding how urban metabolic flows and the networks that connect them are controlled and socially mobilized for particular purposes, usually in the interest of the elite to achieve or maintain positions of social power, and often at the expense of marginalized populations [11], [12].

Finally, political geographers are more interested in the social and distributive impacts on cities, analysing the urban inequality of material and non-material flows and the role that infrastructure networks and spatial patterns of urbanization play in the creation and reproduction of patterns of urban inequality within the city [8], [13].

In this work, it is considered that the discipline most closely related to its approach would be that of urban ecology and ecological economics, because on the one hand, the flow of resources needed for the functioning of the city (like water, energy, materials, food) are analysed, as well as the rejection of transformation processes (such as organic waste, $\mathrm{CO}_{2}$ emissions, inorganic waste), and trying to minimise them by means of maximum reuse, which leads us in a circular process to economise on the need to generate new resources, reducing production and improving environmental conditions. In this process, there is a first phase linked to ecological-related thought and a second phase of environmental cost reduction that is linked to ecological economic thought.

\section{METHODOLOGY}

In this section, we discuss the ambit; the data used; and finally, the method followed to obtain a model of energy consumption and $\mathrm{CO}_{2}$ emissions from the urban fabric.

The city of Almassora is located in the Comunitat Valenciana (Valencian Community region) on the Mediterranean coast of Spain, just $4 \mathrm{~km}$ from the provincial capital of Castellón de la Plana (Fig. 1). It is a municipality of intermediate size that has 25,648 inhabitants (as per the municipal census of 2017) and an area of $32.98 \mathrm{~km}^{2}$. Almassora presents a typical urban model of the coastal plain of Valencian community that is composed of three urban settlements: first, in the centre of the municipality, where the historic centre began, the main core was developed, maintaining a relatively compact structure; second, to the east and close to the sea, a coastal nucleus developed, where an urban fabric of both low and high density coexist, linked to tourist and seasonal beach activity; and third, to the southwest, an extensive very low density area with single-family homes built more or less spontaneously without planning, known as Santa Quiteria.

Regarding our housing data: houses were located and classified based on the "Cadastral data" available within the Ministry of Finance and Public Function website of the Spanish Government. The database reflects all the cartographic and alphanumeric information of the unprotected Cadastre. It includes information on urban and rural properties. In the urban part, the plots, constructive units or buildings are represented. Their description of real estate includes its physical, economic and legal characteristics. In addition to the graphic representation, the location and the Cadastral reference, the surface, the use, the kind of crop or use, the quality of the constructions, the Cadastral value and the Cadastral holder are provided, although these last two are considered protected data. This information is provided through a series of files in CAT format, the Cadastre format. In this case, Type 14 file was used. It contains the construction record database, where there is a record for each construction of each constructive unit in each cadastral plot. 


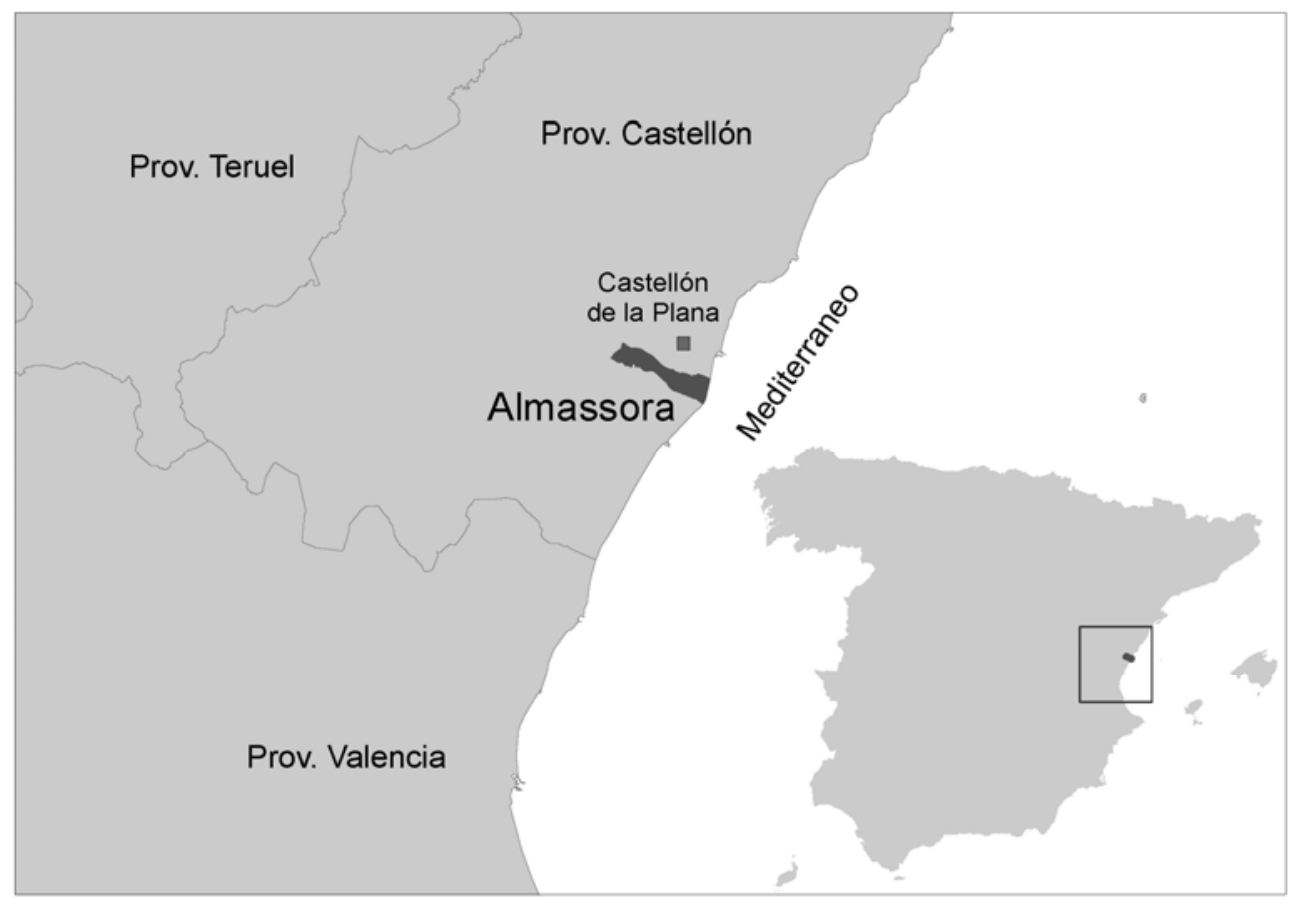

Figure 1: Location of the area of study.

Table 1: Typological classification of residential buildings [14].

\begin{tabular}{|c|c|c|c|c|}
\hline $\begin{array}{c}\text { Construction } \\
\text { year class }\end{array}$ & $\begin{array}{c}\text { Single-family } \\
\text { house (SFH) }\end{array}$ & $\begin{array}{c}\text { Terraced house } \\
(\mathrm{TH})\end{array}$ & $\begin{array}{c}\text { Multi-family } \\
\text { house (MFH) }\end{array}$ & $\begin{array}{c}\text { Apartment } \\
\text { block (AB) }\end{array}$ \\
\hline$<1900$ & SFH.01 & TH.01 & MFH.01 & AB.01 \\
\hline $1901-1936$ & SFH.02 & TH.02 & MFH.02 & AB.02 \\
\hline $1937-1959$ & SFH.03 & TH.03 & MFH.03 & AB.03 \\
\hline $1960-1979$ & SFH.04 & TH.04 & MFH.04 & AB.04 \\
\hline $1980-2006$ & SFH.05 & TH.05 & MFH.05 & AB.05 \\
\hline$>2007$ & SFH.06 & TH.06 & MFH.06 & AB.06 \\
\hline
\end{tabular}

The methodological approach starts with a classification of the different urban plots in the municipality of Almassora, taking into account building characteristics. Then, a typology according to the classification proposed by the Residential Building Typology Catalog (Table 1) of the Instituto Valenciano de la Edificación (IVE) [Valencian Institute of Edification] is assigned to each plot [14].

Typological classification of the residential buildings of the IVE, shown in Table 1, are assigned to each building according to the building's typology and either year of construction or last year of rehabilitation of the house (in CAT file Type 14), and the height data appearing in the Cadastre construction shape. The height was used to differentiate between multi-family homes inferior to five stories (MFH) and multi-family homes greater than five stories, or apartment buildings (AB). 
Once the typological classification of residential buildings was established, a module of energy consumption per $\mathrm{m}^{2}$ built (Kilowatt hours per meter squared or $\mathrm{KWh} / \mathrm{m}^{2}$ ) and another of $\mathrm{CO}_{2}$ emissions per $\mathrm{m}^{2}$ (Kilogram $\mathrm{CO}_{2}$ per meter squared or $\mathrm{Kg} / \mathrm{m}^{2}$ ) was assigned to each house (Table 2).

With Table 2 values and the building type established for the different plots obtained through the Cadastre, the buildings' consumption and $\mathrm{CO}_{2}$ emissions within the municipality can be georeferenced and represented.

\section{RESULTS: ENERGY USE AND $\mathrm{CO}_{2}$ EMISSIONS}

A classification of the houses was made and the different plots represented according to the building typology established by the IVE, as part of these results. On the one hand, we obtained a map with the home age, representing the plots according to their year of construction or rehabilitation (Fig. 2); on the other hand, we obtained another map with the type of building according to the following single-family classification single-family detached house, single-family semi-detached, multi-family up to five floors and multi-family if over five floors (Fig. 3).

Applying the methodology developed in the previous point, we obtained two more maps of the main core of Almassora cadastral plots with existing residential use: a cartographic representation of energy consumption per square metre of housing $\left(\mathrm{KWh} / \mathrm{m}^{2}\right.$ and year) (Fig. 4) and another map of the $\mathrm{CO}_{2}$ emissions per square metre of housing (Kg/m² ; year) (Fig. 5).

Table 2: Modules of energy and $\mathrm{CO}_{2}$ emissions according to building typology [14].

\begin{tabular}{|c|c|c|}
\hline $\begin{array}{c}\text { Residential } \\
\text { building type }\end{array}$ & $\begin{array}{c}\text { Energy consumption per } \\
\mathrm{m}^{2}\left(\mathrm{KWh} / \mathrm{m}^{2} \text { per year }\right)\end{array}$ & $\begin{array}{c}\mathrm{CO}_{2} \text { emissions per } \mathrm{m}^{2} \\
\left(\mathrm{Kg} / \mathrm{m}^{2} \text { per year }\right)\end{array}$ \\
\hline AB.01 & 149.6 & 67.5 \\
\hline AB.02 & 101.7 & 54.4 \\
\hline AB.03 & 155.3 & 60.1 \\
\hline AB.04 & 84.1 & 27.4 \\
\hline AB.05 & 39.9 & 12.4 \\
\hline AB.06 & 37.8 & 11.7 \\
\hline MFH.01 & 157.2 & 78.7 \\
\hline MFH.02 & 82.8 & 39.3 \\
\hline MFH.03 & 85.5 & 40.8 \\
\hline MFH.04 & 76.9 & 34.2 \\
\hline MFH.05 & 29.5 & 12.3 \\
\hline MFH.06 & 33.0 & 10.4 \\
\hline SFH.01 & 107.2 & 60.2 \\
\hline SFH.02 & 308.8 & 113.7 \\
\hline SFH.03 & 102.5 & 42.0 \\
\hline SFH.04 & 198.5 & 89.1 \\
\hline SFH.05 & 99.6 & 32.2 \\
\hline SFH.06 & 49.2 & 16.7 \\
\hline TH.01 & 150.2 & 57.6 \\
\hline TH.02 & 251.0 & 109.2 \\
\hline TH.03 & 172.3 & 73.2 \\
\hline TH.04 & 100.9 & 38.0 \\
\hline TH.05 & 64.5 & 45.5 \\
\hline TH.06 & 34.8 & 14.5 \\
\hline & & \\
\hline
\end{tabular}




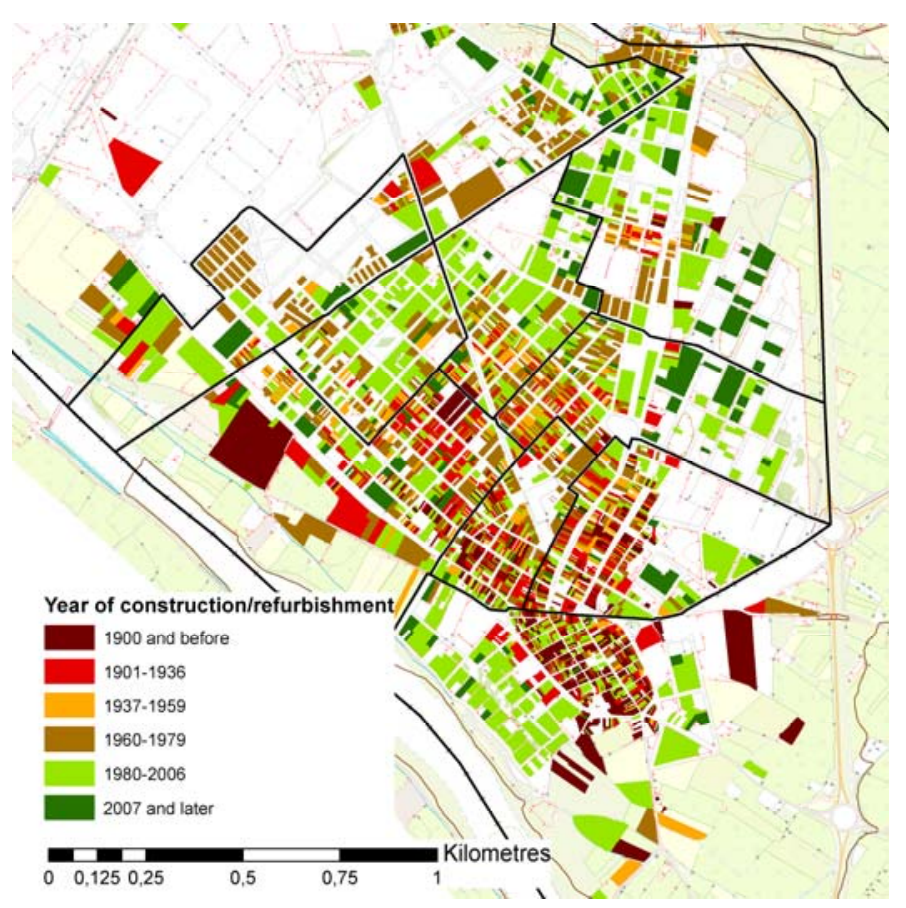

Figure 2: Year of construction/refurbishment of housing.

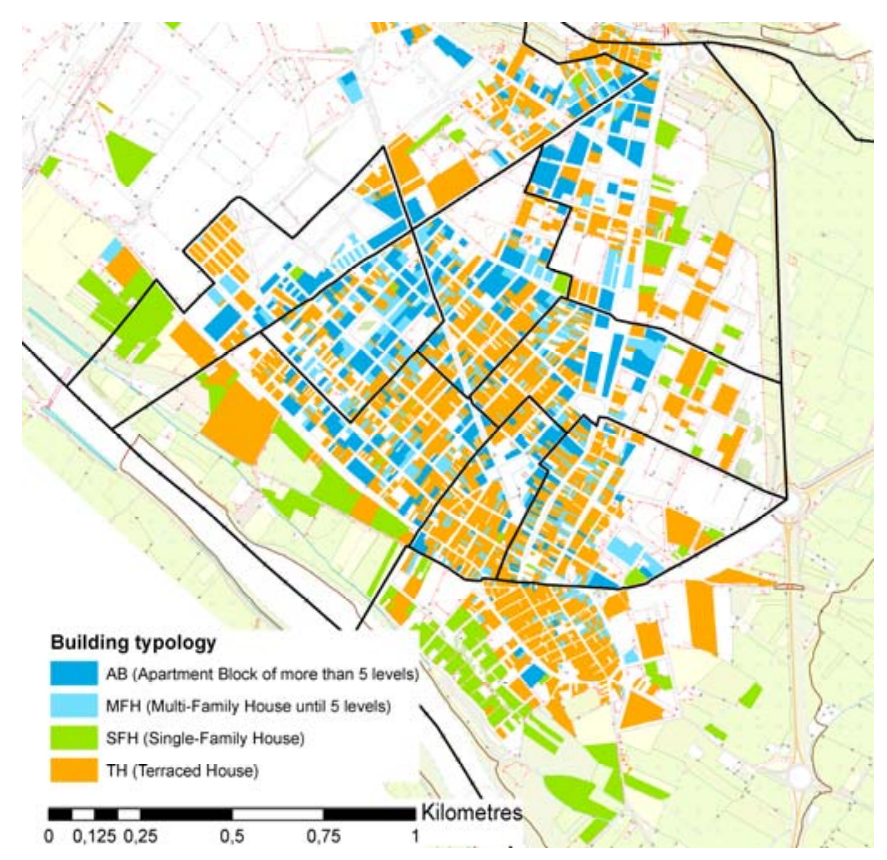

Figure 3: Building typology. 


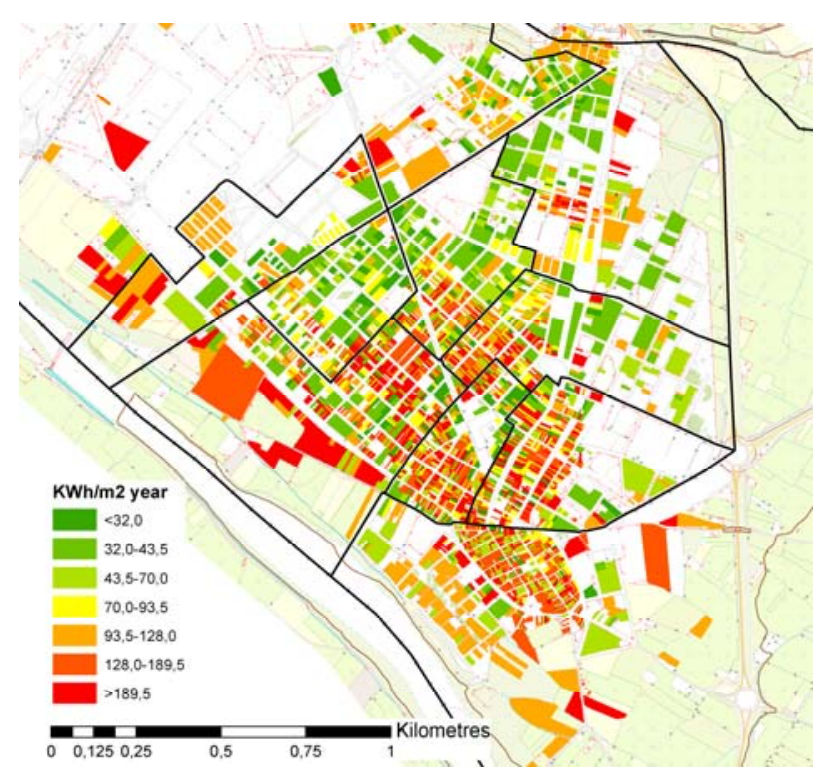

Figure 4: Energy consumption per square metre of housing $\left(\mathrm{KWh} / \mathrm{m}^{2}\right.$ per year).

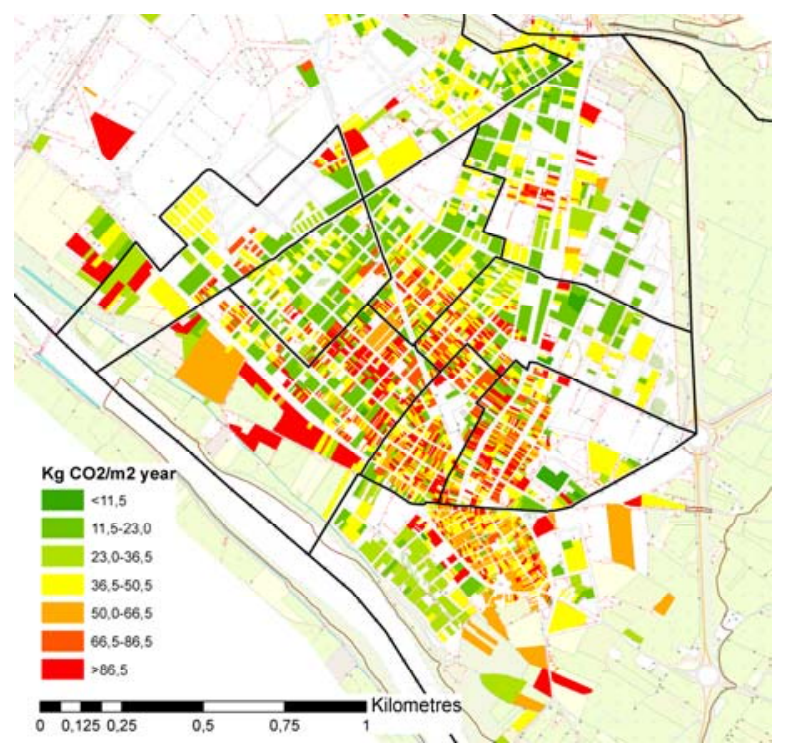

Figure 5: $\mathrm{CO}_{2}$ emissions per square metre of housing $\left(\mathrm{Kg} / \mathrm{m}^{2}\right.$ per year).

Calculating the energy consumption and total $\mathrm{CO}_{2}$ emissions, according to the square metres built in each plot, the maps shown in Figs 6 and 7 were obtained.

At the municipal level in Almassora, residential activity produces an energy consumption of 135,169.6 MW per year and carbon dioxide $\left(\mathrm{CO}_{2}\right)$ emissions of $65,216.8$ tons per year. 


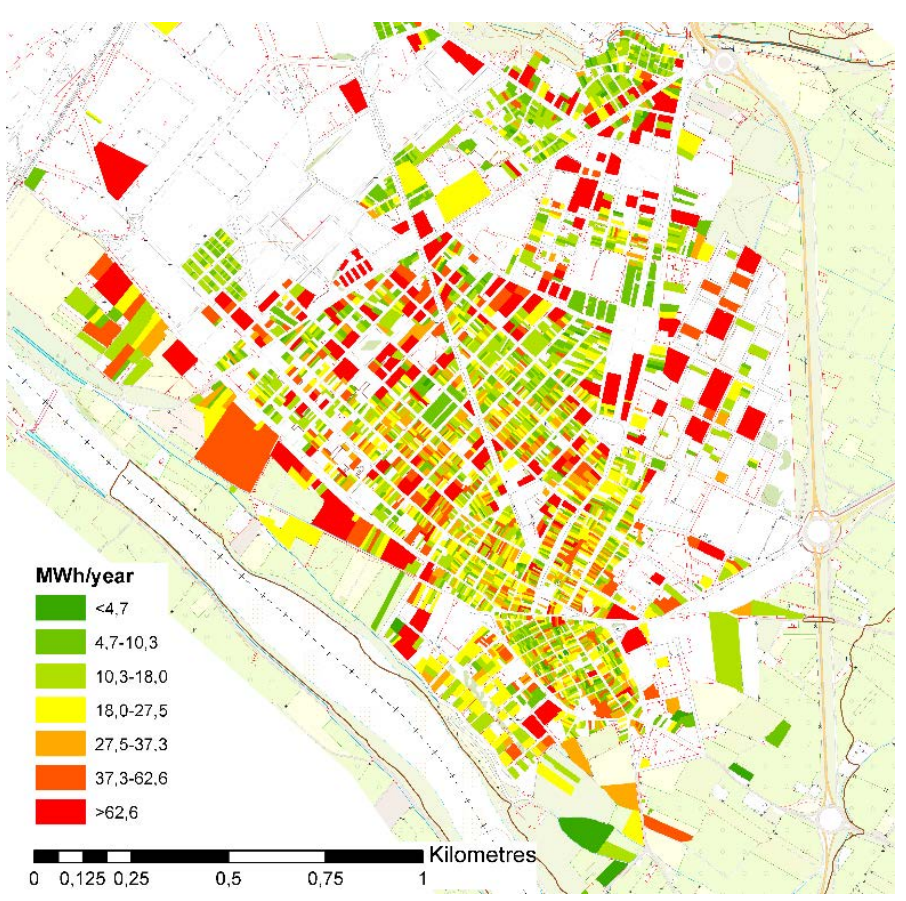

Figure 6: Total energy consumption at the cadastral parcel level (MWh per year).

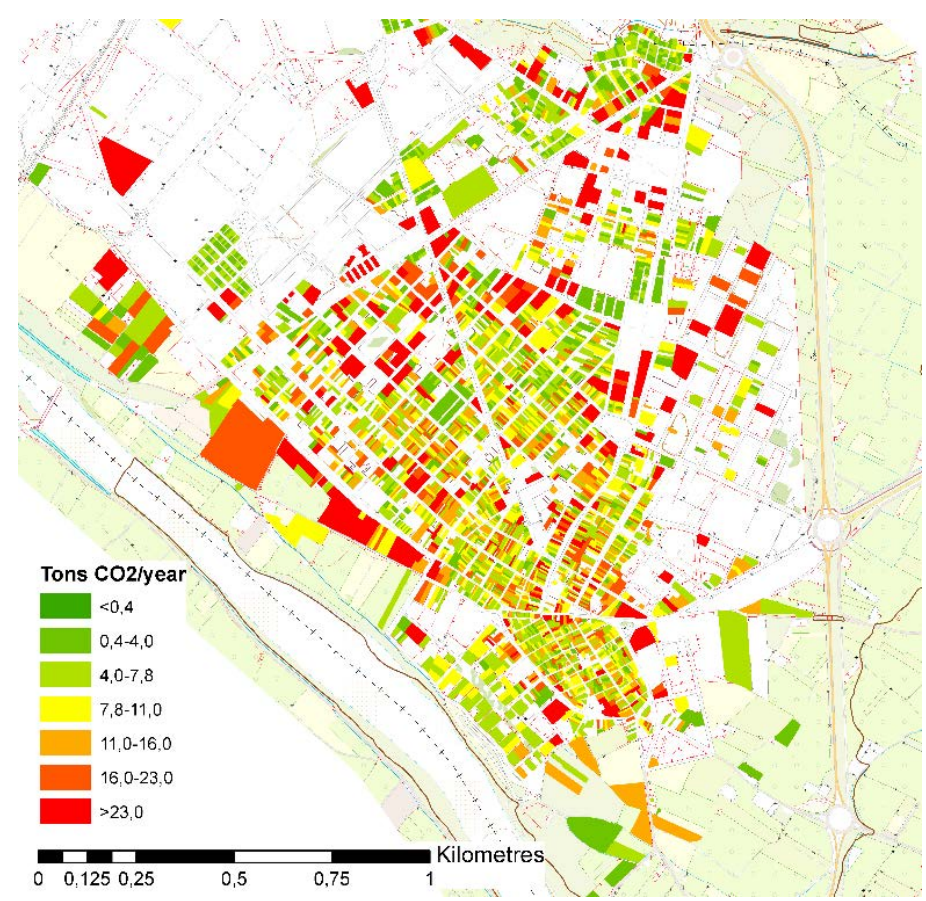

Figure 7: Total $\mathrm{CO}_{2}$ emission at the cadastral parcel level (tons per year). 


\section{ANALYSIS AND DISCUSSION}

The tables and maps generated show expected results, which in any case facilitate a global view of the "energy metabolic function" of the Almassora nucleus.

According to the IVE modules used, the least efficient buildings are the oldest and correspond to the single-family type. The residential urban fabric of the multi-family type $\mathrm{AB}$ and MFH (Fig. 3) are shown as the most efficient per square metre of housing, both from the point of view of energy consumption (Fig. 4) and by a lower generation in carbon dioxide emission (Fig. 5). Metabolic differences between the different urban forms can be visualized through the various rings or zones of urban growth that were identified in Fig. 2 (where the date of construction or rehabilitation of the houses appears); therefore, it was observed that efficiency in energy consumption decreases with the type of single-family house and its antiquity. This reality would make the use of multi-family dwellings recommendable.

The residential fabric of the multi-family housing type are also those with the highest housing density, which means a higher concentration of energy consumption and generation of carbon dioxide emissions (Figs 6 and 7). Considering the sum of dwellings, in spite of a higher efficiency per square metre, the footprint corresponding to plots with multi-family dwellings generates, in absolute values, higher carbon dioxide emissions and higher consumption. There are high concentrations of $\mathrm{CO}_{2}$ emissions in areas where the multifamily type of housing predominates, as there are also more people and homes. In addition, the age of some of them is a negative factor that could be corrected by rehabilitation.

Regarding the energy balance of the house, the production of the energy consumed is generated in areas outside the municipality of Almassora, since there are no sources of energy generation in Almassora; therefore, the production of carbon dioxide derived from the generation of the energy consumed is not perceived within the municipality of Almassora. In fact, if we estimate the carbon footprint in the current scenario, without incorporating improvements on the construction elements, to absorb the emitted 65,216.8 tons of $\mathrm{CO}_{2}$ per year, an approximate arboreal area of 8,150 hectares would be needed. This area is equivalent to 2.4 times the total area of the municipality, which indicates that it will be necessary to offset the absorption of $\mathrm{CO}_{2}$ in a de-localized manner in rural municipalities located in the interior of the province of Castellón.

In a future scenario in which improvements were made on the construction elements studied, such as those proposed by the IVE [14], achieving a $61.5 \%$ savings in $\mathrm{CO}_{2}$ emissions, the footprint would be reduced to 0.94 times the surface of the municipal area. Even though it remains high, even considering that the balance is not complete and there are still variables to be analysed in future research, our results show the opportunity to intervene in the built urban fabric and to start reflections on new urban growth and how to design it, to achieve a reduction in energy consumption.

\section{CONCLUSIONS}

An approximation similar to the calculation made for the housing and energy metabolic functions could be completed with the other components of urban metabolism (water, waste, productive land, and green infrastructure) to achieve a global vision of the municipality.

In this first work, we focused on energy consumption and $\mathrm{CO}_{2}$ emissions of city homes, observing the important role they play in the ecological footprint they generate. The typology of the most efficient building, in terms of energy matters, indicates that the model of urban development that can generate lower emissions and consumption is the compact model of multi-family dwelling with an open urban morphology, that is to say, with free spaces interspersed between the buildings. 
The results obtained show that it is necessary to opt for multi-family dwellings that allow establishing a greater number of open spaces, which facilitate the implementation of a certain mixture of use that can be places for producing local energy and $\mathrm{CO}_{2}$ absorption, allowing the nucleus to be self-sufficient, minimizing imports and exports.

This work is a first approach to a problem. It would be necessary to complete the problem with modelling of more urban metabolism components, which can even be converted to $\mathrm{Kg}$ of $\mathrm{CO}_{2}$ emitted, for later integration into a single model presenting the final balance.

This metabolic approach to the city provides an interesting planning tool. A city that is planned and managed with sustainability criteria would have to introduce a circular type metabolic vision: this would make it possible to move towards a zero $\mathrm{CO}_{2}$ balance, where clearly surplus areas or plots will have to be compensated for either by other metabolic components and functions, or by other parts of the municipality that allow generation of the large amount of energy required and absorption of the large amount of $\mathrm{CO}_{2}$ produced.

\section{ACKNOWLEDGEMENT}

This work was possible thanks to an Urbanism Department student collaboration grant, awarded by the Ministry of Education, Culture and Sport of Spain.

\section{REFERENCES}

[1] United Nations (UN), World Urbanization Prospects 2011 Revision, New York, 2012.

[2] Agencia Europea de Medio Ambiente (AEMA), El medio ambiente en Europa: Estado y perspectivas 2015 [The environment in Europe: State and perspectives 2015]. AEMA Summary Report, Copenhagen, 2015.

[3] European Commission, Investing in Europe's future. Fifth report on economic, social and territorial cohesion, EU Commission Publications Office, 2010.

[4] Observatorio de la Sostenibilidad en España (OSE), Cambio Global España 2020/50: Programa Ciudades. Hacia un pacto de las ciudades españolas entre el cambio global icono barra herramientas [Global Change Spain 2020/50: Cities Program. Towards a pact of spanish towns...], Fundación General de la Universidad Complutense de Madrid/Fundación CONAMA, 2009.

[5] Wolman, A., The metabolism of cities. Scientific American, 213(3), pp. 179-190, 1965.

[6] Dinarès, M., Urban metabolism: A review of recent literature on the subject. Documents d'Anàlisi Geogràfica, 60(3), pp. 551-571, 2014.

[7] Decker, E.H., Elliott, S., Smith, F.A., Blake, D.R. \& Rowland, F.S., Energy and material flow through the urban ecosystem. Annual Review of Energy and the Environment, 25, pp. 685-740, 2000.

[8] Broto, C.V., Allen, A. \& Rapoport, E., Interdisciplinary Perspectives on Urban Metabolism. Journal of Industrial Ecology, 16(6), pp. 851-861, 2012.

[9] Ferrão, P. \& Fernández, J.E., Sustainable Urban Metabolism, MIT Press: Cambridge, MA, 2013.

[10] Daly, H.E. \& Farley, J.C., Ecological Economics: Principles and Applications, Island Press: Washington, DC, 2004.

[11] Otero, I., Kallis, G., Aguilar, R. \& Ruiz, V., Water scarcity, social power and the production of an elite suburb: The political ecology of water in Matadepera, Catalonia. Ecological Economics, 70(7), pp. 1297-1308, 2011.

[12] Swyngedouw, E. \& Heynen, N.C., Urban political ecology, justice and the politics of scale. Antipode, 35(5), pp. 898-918, 2003. 
[13] Monstadt, J., Conceptualizing the political ecology of urban infrastructures: Insights from technology and urban studies. Environment and Planning A, 41(8), pp. 19241942, 2009.

[14] Instituto Valenciano de la Edificación (IVE) [Valencian Institute of Edification], Catálogo de tipología edificatoria residencial [Residential Housing Construction Typology Catalog], IVE: Spain, 2016. 